\title{
Article \\ Problematising the Islamic Theology of Religions: Debates on Muslims' Views of Others
}

\author{
Esra Akay Dag
}

Citation: Akay Dag, Esra. 2022. Problematising the Islamic Theology of Religions: Debates on Muslims' Views of Others. Religions 13: 223. https: / / doi.org/10.3390/ rel13030223

Academic Editor: Terry Lovat

Received: 14 February 2022

Accepted: 3 March 2022

Published: 6 March 2022

Publisher's Note: MDPI stays neutral with regard to jurisdictional claims in published maps and institutional affiliations.

Copyright: (c) 2022 by the author. Licensee MDPI, Basel, Switzerland. This article is an open access article distributed under the terms and conditions of the Creative Commons Attribution (CC BY) license (https:/ / creativecommons.org/licenses/by/ $4.0 /)$.
Department of Philosophy and Religious Studies, Theology Faculty, Sakarya University, Sakarya 54050, Turkey; esraakaydag@sakarya.edu.tr

\begin{abstract}
Race's typology has been widely used outside of the Christian tradition; however, it has been constructed in the light of the epistemological and soteriological concerns raised by Christian approaches towards other religions. Even though different questions generate the Christian and Islamic theologies of religions, Muslim and non-Muslim scholars have used Race's classification to present the Islamic theology of religions. This paper presents different usages of Race's threefold typology and shows that Race's threefold classification is not fully applicable to the Islamic theology of religions. The inclusivist position in the Islamic theology of religions (or its application to them) seems to be the most problematic issue. This is not because no inclusivist theology exists in the Islamic theology of religions, but rather because some scholars emphasise soteriology when applying Race's inclusivism to the Islamic theology of religions, whilst others take epistemological concerns into account. Unlike these scholars, this paper eventually offers that contemporary Muslim theologians offer two-sided arguments. The supersessionist theory (Islam is the only true religion that supersedes other religions) is the best way to distinguish between these positions. According to Knitter's classification, this paper considers this theory as a form of exclusivism, which would be seen as the "Replacement Model". Contemporary discourse on the Islamic response to religious pluralism takes place between exclusivists who believe that Islam is the only religion that has superseded other religions and pluralists who think the opposite.
\end{abstract}

Keywords: three-fold typology; exclusivism; inclusivism; pluralism; supersessionist theory; Islam

\section{Introduction}

There have been diverse approaches towards other religions in the Christian West in the last two centuries. With the growing awareness of religious pluralism, Christian theologians have started to relate Christianity to other religions. While doing so, they have questioned the nature of non-Christian religions and the status of the believers of other faiths. Different responses to these have led Christian academics to shape a specific intellectual subtopic within Christian theology, namely the theology of religions. Since the publication of Christians and Religious Pluralism in 1983, Alan Race has categorised diverse approaches to religious pluralism into three taxonomies: exclusivism, inclusivism, and pluralism. Since then, his three-fold typology has become the standard typology used to picture the Christian theology of religions despite some critiques. ${ }^{1}$

Even though Muslims have responded to religious plurality since the beginning of Islam, ${ }^{2}$ there have not been such diverse responses as there currently are today. With the growing awareness of religious diversity in the West, some Muslim academics also have developed different approaches towards non-Muslims. Recently, some Islamic scholars have also started to use the terminologies from the Christian theology of religions within Islamic theology. In doing so, some of them have transformed the terminologies from the Christian circle and have adapted them to Islamic theology. Race's three-fold typology has become the standard marker for the identification of the Islamic theology of religions. 
In recent decades, Muslim academics have produced essential works that question the place of others within the Islamic faith. Although there have been relatively diverse responses to this question, fewer works have categorised these responses. It seems that scholars have primarily used Race's three-fold typology to explore different Islamic responses to religious others. In this article, I will question the applicability of Race's classification into the Islamic theology of religions. While doing so, I will focus on the contemporary discussions on the subject. As the theology of religions is a Western-based subject, its application to Islam has also mainly been determined by the Western-based Muslim scholars, though they do come from different parts of the Islamic world. Thus, the literature on this matter has generally been in English. This article will also focus on the literature written in English.

In this paper, I will survey recent usages of Race's three-fold typology in Islamic discourse and will look at how scholars, such as Rifat Away, Levis Winkler, and Mohammad Khalil, who write on the Islamic theology of religions, use this typology. In addition to Race's threefold typology, I will explore Jerusha Lamptey's three-fold typology as she tries to depart from using settled typology. After looking at the different usages of three-fold typologies, this paper will argue that although scholars try to fit Islamic responses to religious pluralism into either Race's typology or other three-fold typologies, it appears that there have been two main different positions within the Islamic theology of religions: exclusivism and pluralism.

On the one hand, some Muslims view Islam as the only valid religion and that it supersedes other religions; on the other hand, some others claim the opposite view and argue that non-Islamic religions are valid and can also lead to salvation. Thus, this paper eventually argues that any three-fold typology does not entirely paint the right picture of Islamic discourse on religious others. The primary reason for this is that there are some fundamental differences between the Christian and Islamic theologies of religions.

\section{Race's Three-Fold Typology}

Before presenting different three-fold typologies in the Islamic theology of religions, it is better to demonstrate how a three-fold typology was initially used in the Christian theology of religions. In 1983, Alan Race, presented his three-fold typology of Christian views of other religions via his publication Christians and Religious Pluralism. Although he admits that the Christian approach to other religions is not new (Race 1993), he thinks that the growing awareness of pluralism and literature about the subject results in the co-ordination of Christian views (Race 1993), which he achieves by offering a three-fold typology.

First, Race explains exclusivism by presenting two Biblical texts ${ }^{3}$ through which exclusivism can be formulated: salvation is only possible through Jesus Christ. He does not provide an exact definition of exclusivism, but he presents the approaches of Protestant theologians, such as Barth, Brunner, and Kramer's views, as examples of exclusivism. Citing Kraemer's views on religion, Race offers that exclusivism can be viewed "as the revelation in Jesus Christ as the sole criterion by which all religions, including Christianity, can be understood and evaluated" (Race 1993). Secondly, he identifies inclusivism as "both an acceptance and a rejection of other faiths, a dialectical 'yes' and 'no'" (Race 1993). He analyses the theologies of Catholic theologians to demonstrate the presence of inclusivism since the Second Vatican Council. According to Race, inclusivism is shaped by two equally binding convictions: God's universal will to save and the uniqueness of the revelation in Christ (Race 1993). The second part is shared by exclusivism, whereas the first part is part of pluralistic theology. Finally, Race explains pluralism with a connection to tolerance. By tolerance, he does not only include a moral imperative, as he thinks even exclusivist theologians would agree, but he also stresses a Christian theological necessity. Thus, he explains pluralism by saying that "knowledge of God is partial in all faiths, including Christian faith. Religions must acknowledge their need of each other if the full truth about God is to be available to all mankind" (Race 1993). He presents the theologies of Christian liberal theologians to exemplify pluralist theory. 
Since he announced these three categories, they have been widely used within Christian theology and outside of the Christian tradition. While some theologians have used the same typology, ${ }^{4}$ others have modified the typology ${ }^{5}$ and have used it with the additional categories. ${ }^{6}$ Despite critiques against Race's typology, ${ }^{7}$ three categories are still decisive in the Christian theology of religions. ${ }^{8}$ Even though Race formulates these categories in light of Christian theological terminology, they have also been used in a more broad sense. Recently, a three-fold typology has been defined as follows:

"Exclusivisms: only my religion is true; all other religions are false and lead people astray. God or a transcendent reality has ordained one path to lead people to Him (Her/It) and failure to follow this means you are not included in the chosen or elect.

Inclusivisms: while my religion is the most true, God or a transcendent reality is known to all humanity and so other religions are ways leading towards the truth found in my tradition. True followers of other religions will come to the truth in my religion eventually. Pluralisms: I simply do not know if there is only one true religion or many true religions. Followers of other religions have a depth of prayer life, insight into truth, spiritual aspirations, and ethical ideals which at least equal my own. If God is as loving and big as I believe Her/Him to be, or if liberation is intended for all, I cannot limit truth to just the path I know (Harris et al. 2016)."

There are two things worth mentioning about the nature of the three-fold typology that I think make it difficult to apply to the Islamic theology of religions. Firstly, it is clear that Jesus Christ plays an important role in the development of any of the existing three-fold theologies. As a result, while this typology has been transposed to Islamic theology, it becomes difficult to find something equivalent to Christ. Secondly, it is clear from Race's classification that whilst exclusivist theory represents the mainstream Protestant theology, the theologies of Catholic theologians fit into inclusivism. However, there are not as many instances of different denominations, such as the Sh'̈'a and Sunni denominations in the Islamic tradition, taking such different positions. Even though Sufism has historically been considered to be a more pluralistic option than any of the other orthodox theologies, there is not enough enough evidence that Sufis promote pluralism despite Sufis such as Ibn 'Arabī and Rumi being used as a point of reference by different scholars to prove their own position. ${ }^{9}$ For example, while Khalil believes the form of theology that Ibn 'Arabī offers is inclusivist, Shah-Kazemi thinks Ibn 'Arabī offers a universalist view of others. My aim here is not to discuss whether the Sufis theology is pluralist, inclusivist, or universalist. My point is that in the contemporary period, Sufi thinkers tend to be used as a justification for any view.

\section{Three-Fold Categories in Islamic Theology of Religions}

As pointed out previously, the academic discipline of the theology of religions originated in Western Christianity. However, in the contemporary era, Muslims have not engaged with this discipline as systematically as Christians have. Nevertheless, contemporary the proposals from liberal Christian theologians have influenced the development of Islamic pluralist approaches by liberal Muslim theologians, who have produced several essential and systematic works on the subject in the last four or five decades. Even though there are fewer diverse typologies to classify the response of Muslims' to religious pluralism, the so-called pluralist Muslim theologians have proposed pluralism through their works in opposition to the traditional understanding of religious others. I should also note that not all theologians who are regarded as pluralists identify as pluralist themselves, but in most cases, they are considered to be pluralists by others. For example, in Schmidt-Leukel's recent works (Schmidt-Leukel 2016, 2017), he identifies Mahmut Aydin, Mahmoud Ayoub, Ashgar Ali Engineer, Hasan Askari, Abdulaziz Sachedina, Imtiyaz Yusuf, Jerusha Lamptey, Rifat Atay, Abdolkarim Soroush, Seyyed Hosain Nasr, and Reza Shah-Kazemi as Muslim pluralist theologians when presenting Islamic pluralism. Those mentioned above write 
about religious pluralism in Islam, though, as we shall see, they are not classified as being in the same category by academics while analysing the Islamic theology of religions.

Islamic scholars tend to use Race's three-fold categories while responding to Islamic views of religious others. Some theologians use Race's categories to justify their own pluralistic position without applying the three different categories to the Islamic theology of religions. On the other hand, others apply Race's classifications to Islam. Khalil, Atay, and Winkler are in this group. When they present the Islamic theology of religions, they prove that Race's classifications find an echo in the Islamic circle. Similarly, I will address these scholars' application of Race's classification to their own maps.

\section{Khalil's Application of Three-Fold Typology}

Muhammad Khalil (Khalil 2012), in Islam and the Fate of Others, used Race's typology by arguing that "Islam has developed its own unique currents of soteriological intra- and ..., interreligious exclusivism, inclusivism, and pluralism" (Khalil 2012). The book's main purpose is to demonstrate different versions of inclusivism, which he favours, but he also evaluates exclusivist and pluralist theologies.

In detail, he first describes exclusivism as the position that there is only one religious tradition or interpretation of that tradition that leads to salvation and that the followers of other beliefs will be punished in hell (Khalil 2012). For exclusivism, he uses the traditionalist theologian Ibn Hazm, whose theology does not accept that unreached people that would be excused (Khalil 2012). Khalil considers political Islamists' view on the salvation of non-Muslims as a form of exclusivism. He mainly evaluates Sayyid Qutb, who considers Islam to be the only true religion; thus, only righteous Muslims are upright, and all others who reject Islam are ignorant and astray (Khalil 2012).

Secondly, he interprets inclusivism as the position that only one religion leads to Heaven but that the "sincere outsiders who would not have recognised it as such will be saved" (Khalil 2012). Four chapters of his book are dedicated to different forms of inclusivism. He evaluates, in subsequent chapters, Ghazālī, Ibn 'Arabī, Ibn Taymiyya, and Rashid Ridā's theologies on the salvation of non-Muslims and argues that the four of them represent "different shades of inclusivism" (Khalil 2012), though each of them offered different views on non-Muslims. He classifies Ibn 'Arabī as a quasi-universalist, Ibn Taymiyya as a limited inclusivist, and Ridā as an ultimate universalist. ${ }^{10}$ He does not evaluate each of theologian's views on a possible Islamic theology of religions (such as supersessionist theory), but rather tries to prove that each of them includes non-Muslims in God's universal will of salvation. From the contemporary period, he cites Tim Winter ${ }^{11}$ and Muhammad Legenhausen's theology of religions as examples of inclusivism (Khalil 2012).

Finally, with regard to pluralism, he thinks that it is to affirm that "regardless of circumstances, there are several religious traditions or interpretations that are equally effective salvifically" (Khalil 2012). He evaluates the views of Farid Esack, Abdulaziz Sachedina, Mahmoud Ayoub, Seyyed Hosain Nasr, and Reza Shah-Kazemi's to exemplify Islamic pluralism. ${ }^{12}$ Despite differences in nuances, the main similarity of their positions is that each would distinguish their theology from traditional forms of theology. Furthermore, each would accept that non-Islamic religions would lead to salvation as well as Islam.

Unlike Race, Khalil is not concerned with religious epistemology, although he takes soteriology seriously, and this shapes his interpretation of the question of whether salvation is possible outside of the Islamic faith. It seems that his interpretation is different from Race's interpretation. As noted before, Race deals with epistemological problems. His definition of inclusivism is broader than Khalil's. In the introduction of his book, Khalil divides inclusivism into two categories: limited inclusivists and liberal inclusivists. Limited inclusivists argue that among non-Muslims, only the unreached will be saved, while liberal inclusivists maintain that "the category of sincere non-Muslims includes individuals who have been exposed to the message in its true form yet are in no way convinced" (Khalil 2012). The criterion here is whether the message of Islam has reached a non-Muslim or not. If it has not, it is the first category. If it has, and a non-Muslim is not convinced and does not 
accept the message, then it is the second category. While Khalil's limited inclusivism can be fitted easily to Race's exclusivism, his liberal inclusivism is equal to D'Costa's universalaccess exclusivism ${ }^{13} \mathrm{I}$ am not arguing that Khalil's justification is wrong; however, from my perspective, the main criterion to justify a position as being inclusivist or exclusivist is whether the position accepts the salvific means from non-Islamic traditions. In terms of Islam, they can be divided based whether one accepts Islam as the only true religion or supersedes other religions (exclusivism) or whether one accepts non-Islamic religions as valid but not as true as Islam (inclusivism).

\section{Atay's Application of the Three-Fold Typology}

Another Muslim theologian, Rifat Atay, also uses Race's classification to picture the Islamic theology of religions. Atay (Atay 2014) first examines Race's threefold classification in the Christian context (Atay 2014) and then applies it to the Islamic theology of religions. First, he identifies exclusivism in the Islamic context as the idea that "Islam is the final and full religion for humanity as put forward in the Qur'ān as a way of life" (Atay 2014). He evaluates such verses in the Qur'ān that could be used as a justification for exclusivist theory. For the exclusivist form of religious theology, he uses Imam Abu Mansur al-Māturīdī (Atay 2014) as an example theologian. The main reason why he chooses Māturīdī is that he believes that Muslim communities have widely accepted Māturīdī's exclusivist views, and he also thinks that several contemporary scholars offer almost the same exclusivist theory as Māturīdī's (Atay 2014). While evaluating Māturīdī 's views, he emphasizes the theory of abrogation, which has been traditionally shaped.

Secondly, Atay portrays inclusivism as the theory that "there is one surest way to salvation, which is Islam in Muslims' case, others may lead to salvation but not as good as one's own, i.e., Islam" (Atay 2014). In this case, he uses a Turkish Qur'ānic commentator Süleyman Ateş as an advocator of inclusivist theory. Even though Ateş's ideas are commonly shared by pluralist theologians, and despite the fact that Ateş does not classify himself as an inclusivist, Atay still classifies Ateş as an inclusivist for two reasons: First, for Atay, Ateş has a limited understanding of the concept of the People of the Book. He does not include mainstream orthodox Christians who take Christian doctrines, such as the Trinity, seriously. Second, Atay believes that Ateş's pluralist-sounding theology of religions does not take non-theistic religions into account (Atay 2014). Considering Race's threefold typology, Atay's judgments seem consistent with the original use. However, so-called Muslim pluralist theologians' ideas sometimes overlap with inclusivism. Thus, it is not only Ateş, who takes mainly monotheistic religions seriously, but also so-called pluralist Muslims who sometimes dismiss theistic religions other than Islam, Christianity, and Judaism together with non-theistic religions, or make abstract claims regarding non-theistic religions.

Thirdly, as for pluralism, Atay utilises Hick's form of pluralism as a definition. Pluralism is thus the theory that "the great world religions are each equally efficient ways of perceiving the Real" (Atay 2014). In his section on pluralism, he classes Arkoun's theology of religions as a model of Islamic pluralism. Atay's justification for each class in the typology seems to follow the original threefold typology introduced by Race. However, I still think that there are mainly two general trends in contemporary discourse: exclusivism and pluralism. Atay himself, while evaluating exclusivism and inclusivism, uses two Turkish theologians, Koçyiğit and Ateş, to represent opposing positions. While scholars attempt to apply Race's classification to the Islamic theology of religions, they either interpret each position of the typology differently from the original or spend extra effort to place certain theologians in the inclusivist class.

\section{Winkler's Application of Three-Fold Typology}

Though he is not a Muslim, Lewis Winkler (Winkler 2011) also uses Race's classification in his evaluation of the responses of Muslim theologians to religious pluralism. He defines exclusivism in an Islamic context as the position that refuses to grant salvific and epistemic legitimacy to non-Islamic religions. He thinks all conservative and fundamentalist Muslims 
fall into this category. From the fundamentalist side, he cites Qutb's views on jihad (Winkler 2011) while also admitting that the views of fundamentalists only represent a small portion of Muslims.

Winkler describes inclusivism as something that "is usually expressed in the Islamic terminology of ethical 'submission' and 'obedience' to the commandments of God" (Winkler 2011). He uses Shabir Akhtar, Mahmut Aydin, and Adnan Aslan's views to exemplify the Islamic version of inclusivism. He identifies these scholars as inclusivist because they define Islam as submission to God. According to his definition, the idea that no matter the religion of a person, if they submit their will to God, they are perceived as a Muslim, could be considered as an inclusivist theology and not a pluralist one.

In addition, Winkler sees pluralism as the position that accepts the salvific and epistemological validity of all world religions (Winkler 2011). Here, he interestingly cites Aydin, whom he previously considered to be inclusivist. In fact, Winkler also seems to be aware of the difficulty of differentiating inclusivist and pluralist positions in Islamic discourse. He uses Aydin to represent both inclusivism and pluralism, though he uses different articles to illustrate each position. ${ }^{14}$ Moreover, in the section on inclusivism, he cites Aslan (Aslan 1999) as promoting inclusivism. However, Aslan's arguments are mostly arguments that so-called pluralists also use. The reason why he uses Aslan and Aydin as representatives of inclusivism might not be because both scholars believe they are inclusivists, ${ }^{15}$ but because their pluralistic arguments might be essentially consistent with some inclusivist ideas.

\section{Evaluation of Three Accounts}

From the evaluation of these three applications of Race's typology, it is clear that Atay and Winkler's interpretations differ from Khalil's. While the first two scholars consider religious epistemology with soteriological concerns (in the same way that Race does), Khalil does not consider religious epistemology. Atay and Winkler's interpretation seems to follow the original typology, but it also appears that they have difficulty locating inclusivist theology on the map of the threefold typology. This inconvenience derives from the fact that there is no sharp distinction between what they would describe as inclusivist and pluralistic theologies in the Islamic theology of religions, in contrast to Christian theology. However, in their presentation, the difference between exclusivist and inclusivist/pluralist theology is quite apparent. Thus, rather than applying Race's three distinct types to the Islamic theology of religions, it appears to be more convenient to present a two-sided argument, i.e., exclusivist theology and pluralist theology.

It is considerably clear that the application of inclusivism into the Islamic theology of religions seems to be the most problematic issue. What Khalil considers inclusivism is regarded as exclusivism by the other two scholars. Khalil includes the traditional (conservative) form of theology within inclusivism, whereas Atay evaluates Maturudi's view as exclusivist. The accounts of these scholars contradict each other. Moreover, Winkler's usage of Aydin's theology of religions in two different forms contradicts Race's three-fold typology itself. It would have been much more helpful if he had shown the overlap between Aydin's pluralism and inclusivist theory rather than presenting his theology as both inclusivist and pluralist. Atay and Winkler's judgment of a three-form typology seems to be more accurate than Khalil's. However, their presentation of inclusivism is not persuasive enough to see the difference between inclusivism and pluralism. Thus, it would not be wrong to argue that all three scholars' usage of Race's classification fails to picture the Islamic theology of religions. We see from their presentation that exclusivism and pluralism occupy a central place in contemporary Islamic responses to religious pluralism.

None of the three scholars takes the supersessionist theory as a standing point to differentiate categories. While one of the primary reasons for Atay to utilise Māturīdī's views for exclusivism is Māturīdī's dependence on supersessionist theory, he still follows a three-fold typology and fails to explain sufficiently how Islamic inclusivism is different from pluralistic theory. The supersessionist theory seems to be the best way to judge any view of other religions. Those who accept supersessionist theory consider Islam to be the 
only valid religion in God's eyes, whilst those who oppose this view regard the non-Islamic tradition possessing certain values and possible ways to lead to heaven or salvation. After presenting Lamptey's three-fold typology, I will briefly mention supersessionist theory within Islamic theology.

\section{Lamptey's Three-Fold Typology}

Lamptey analyses the contemporary Islamic theology of religions in light of how theologians appreciate similarities and differences. Unlike the above-mentioned scholars who examine Islamic responses to religious diversity through borrowing Race's typology and applying it to the Islamic theology of religions, Lamptey does not use Race's classification as her primary way of organising the contemporary Islamic theology of religions. She examines contemporary Islamic responses to religious diversity using three different categories: the prioritisation of sameness, the simultaneous affirmation of sameness and difference, and the prioritisation of difference.

The first group, she examines, overemphasises the commonality among religions while ignoring differences. Lamptey examines Engineer (2005), Sachedina (2006), and Aydin (2001, 2005b), and she shows how they fail to see the differences of non-Islamic religions. The common point between these theologians is that each highlights the Qur'ānic verses on the single unity of all religions while disregarding other Qur'ānic verses related to differences. As a result of their overdependence on the sameness of religions and the use of the Qur'ānic verses in that direction, when Lamptey analyses Engineer's pluralism, she claims that Engineer uses the Qur'ānic verses in the same manner as exclusivist theologians (Lamptey 2014). She contends:

... the selective textual methodology (proof texting) that Engineer employs to affirm religious pluralism and stress sameness is the same methodological approach used by other historical and contemporary scholars to arrive at an exclusivist reading of the text that prioritises difference. In both cases, only aspects of the Qur'ān that bolster the respective positions - that is, pluralism or exclusivism - are acknowledged, and all other aspects of the text that run counter to or complexify these conclusions are ignored or summarily dismissed (Lamptey 2014).

She raises similar critiques against both Sachedina and Aydin, contending that Sachedina "reduces the importance of the external differences introduced by revelation" (Lamptey 2014). Similarly, she contends that Aydin oversimplifies religious differences and overemphasises the sameness of religions. She thinks that all three theologians regard differences as boundaries that create conflict. Thus, they devalue and downplay differences and emphasise sameness (Lamptey 2014).

According to Lamptey, the second group confirms religious differences and sameness simultaneously. In the second group, she evaluates the perennial philosophers such as Nasr (2008), Shah-Kazemi (2006), and Legenhausen (2013). Unlike the first group, according to Lamptey, this group attaches importance to religious differences as well. In that form, divine unity is affirmed, and divine unity is regarded as the source of diversity. All three of the above-mentioned theologians offer a vision of pluralism that explicitly contrasts Hick's pluralism and that implicitly contrasts the first model she examined. Rather than considering world religions as historically and culturally conditioned responses to the same Reality (as in Hick's case), they regard diverse religions as being divinely intended. ${ }^{16}$

The third group of theologians Lamptey examines rejects sameness and places much more emphasis on differences to affirm the Islamic faith's superiority. On the one hand, her third group resonates with exclusivist theology of what Atay and Winkler have described; on the other hand, it resonates with Khalil's interpretation of inclusivist theology. In this section, Lamptey primarily evaluates Winter (1999), and interestingly, she also places Legenhausen in this group, as she thinks that Winter and Legenhausen's theologies overlap in certain aspects. Briefly, Winter's theological view regarding non-Islamic faiths is that Islam supersedes all other religions, which are corrupted and no longer valid. Thus, Islam is the only true religion and the one that leads its believers to salvation. Lamptey believes 
that although Winter and Legenhausen construct different forms of religious theology, they generally use similar notions such as supersession, salvation, divine mercy, and tolerance to construct their approaches (Lamptey 2014).

Apart from these three categories, while evaluating the Islamic theology of religions, Lamptey also presents Esack and al-Faruqi as alternatives to those mentioned above. She thinks that both of these scholars suggest different and more acceptable approaches as opposed to the three groups she presents. There seems to be considerable overlap between Lamptey's and Race's respective classifications in certain areas. Her three distinct categories correspond to pluralism, inclusivism, and exclusivism, though her nuance differs from Race. However, it should also be noted that although Lamptey's first and third categories correspond to Race's pluralism and exclusivism, respectively, her second category does not directly correspond to inclusivism. In the second category, she includes a Sufi approach which is considered to be closer to a pluralist theology than an inclusivist one. Furthermore, for Race's classification, the key criterion is whether a particular theology of religions accepts non-Christian religions as valid religions that lead to salvation. Lamptey categorises each response according to whether non-Islamic traditions resemble or differ from Islam. In other words, Lamptey's classification neither takes religious epistemology or soteriology as a starting point, and rather, she constructs her classification with regard to attitudes to the similarities and differences of diverse religions. Despite some similarities, it should be noted that Race's classification is much broader than Lamptey's, as there have been more theological responses to religious pluralism in the Christian tradition.

Lamptey's three-fold typology also fails to provide contemporary Islamic discourse on religious pluralism. She offers her three-fold typology as an alternative to other typologies used in the Islamic context (probably Race's typology), but she does not explore all of the theologians that she examined within her typology. For example, she analyses Esack and Faruqi separately, as she thinks they fit into any of the categories that she has created. This shows that her three-fold typology does not paint the full picture of Islamic responses to religious pluralism. Moreover, after picturing the Islamic theology of religions, she aims to move beyond the categorization of the views of any of the theologians she discusses. This also shows that her three-fold typology is not good enough to provide a contemporary discussion on religious pluralism.

When we compare Lamptey's three-fold typology with the ones used by the other three scholars, we also witness considerable overlap between her first and third group, Atay and Winkler's exclusivism and pluralism, and Khalil's inclusivism and pluralism. What she examined in the second group might resonate with the three scholars' interpretations of pluralism. Thus, it is clear that inclusivism is omitted in Lamptey's typology as well. So far, in the three applications of Race's three-fold typology and Lamptey's typology, the category of inclusivism is the most problematic category. This drives us to the original claim that I made at the beginning of this paper that despite valuable efforts to transpose the Christian theology of religions concepts, such as Race's threefold typology, they have so far failed to be applied. The fundamental reason for this is that the Islamic theology of religions is not preoccupied with the same questions as its Christian counterpart. Unlike these scholars' classifications, I think in the contemporary period, Islamic discourse on religious others is shaped by a two-sided argument. Traditionally formed religious exclusivism and modern socio-politic religious exclusivism, on the one hand, and Islamic pluralism, on the other hand, occupy Islamic responses to religious pluralism. Within pluralism, some arguments of Muslim theologians might resonate with what has been called inclusivist theory in the Christian theology of religions. For example, Saeed (2020) uses two types of Islamic responses to religious diversity: exclusivism and inclusivism. Exclusivism is seen as a negative attitude towards other religions, while inclusivism is the opposite ${ }^{17}$ Rather than the term "pluralism", he uses inclusivism to identify modern/liberal perspectives in which positive affirmations of non-Islamic religions are contextualised. He thinks the mainstream Islamic perspectives, Sunni and Shī'a, are a dominant theological exclusivist position, while theological inclusivism is presented in the works of a "relatively small but vocal group of 
Muslim scholars". While his project is different from mine, he has successfully identified the problem that a two-sided argument shapes contemporary Muslim perspectives on other religions. Unlike Saeed, I use the term pluralism, as the scholars themselves use that description to represent their position.

It is partly true that for many Muslim pluralist theologians, pluralism falls into inclusivism in a certain respect. It is beyond the scope of this paper to show how each particular Muslim theologian falls into inclusivism in a certain way, but Thomas (2013) rightly claims that Muslim pluralist theologians tend to judge other religions according to the criteria found in Islam. He further states that the criterion of tawhid has played an important role in how Muslim theologians appreciate other religions (Thomas 2013), with Islam treating other religions as domestic disputes within one and single religious family (Thomas 2013). Thus, he describes the positions of so-called Muslim pluralist theologians towards others as inclusivist rather than pluralist. His judgment of pluralist Muslims is largely accurate. The difference between Islamic and Christian pluralism is due to the centrality of the Qur'ân within the Islamic faith. While Christian pluralist theologians can remove Jesus Christ's centrality for the sake of pluralism, ${ }^{18}$ Muslim theologians cannot treat (and have not treated) the Qur'ān in the same manner as Christians have treated Jesus Christ. Thus, rather than removing the Qur'ān from the centre, so-called Muslim pluralist theologians apply different hermeneutical methodologies to the Qur'ān so as to offer a more pluralist vision of it. As a result, Islamic pluralism falls into inclusivism in certain respects, but it does not mean to identify this kind of theology as inclusivist for several reasons. Firstly, we need to accept that Islam and Christianity are constructed with different theological concepts. The place of Christ and the Qur'ān is just an example. Secondly, despite utilising such terminology to construct pluralism, Muslim pluralist theologians do not respond to the same questions as the ones Christians do. To provide just a solid example, while Christian pluralist theologians offer philosophical and theological arguments about the nature of religion(s), God, the divine reality, etc., Muslim theologians, in addition to these kinds of arguments, need to correspond such problems such as whether or not Muslims can be friends with non-Muslims, are allowed to cooperate with non-Muslims, and so on. ${ }^{19}$ Thirdly, even though their theological views can fall into inclusivism, most of the so-called Muslim pluralist theologians identify themselves as pluralists, or their theologies are widely characterised as pluralist theology. ${ }^{20}$

\section{Theory of Supersessionism}

From the early times of Islam, Muslim scholars have addressed the Qur'ānic verses on non-Muslims and have constructed a doctrine that considers Islam as the only true religion. In spite of the Qur'ānic affirmation of certain values of non-Islamic tradition, early scholars developed a supersessionist theory that assumed that Islam superseded other religions. The supersessionism doctrine in Islamic thought has been discussed in the literature of Islamic jurisprudence (uṣul al-fiqh). The Islamic term for supersessionism is naskh, which literally means "to abrogate". The Qur'ān states that "For every verse We abrogate or cause to be forgotten, We bring down one better or similar" (Qur'ān, 2:106). Muslim scholars later developed the theory of abrogation to address which verses have been abrogated. ${ }^{21}$

There have been two different views in response to the abrogation of non-Islamic religions. The first view argues that a law (shāri'a) imposed by a prophet would keep its validity until there is a sign of its abrogation, while the second presupposes that unless the latter announces its continuity, the validity of a law imposed by a certain prophet is terminated by the mission of his successor (Freidman 2003, p. 21). ${ }^{22}$ Regardless of these views, Muslim scholars have used Qur'ānic verses 3:85 and 3:19 to claim that Islam has superseded other religions. ${ }^{23}$ The classic, medieval, and contemporary form of exclusivism has been shaped in the light of supersessionist theory. As Khalil (2011) states, the popular view in both the Sunni and Shiite thought is that the Qur'ān corrects and abrogates the previous revelation. Thus, the positive affirmation of non-Islamic traditions in the Qur'ān has been regarded as abrogated. In other words, the Qur'ānic verses that value the Christian 
and Jewish traditions have been considered to be part of this supersessionist process. Despite its varieties and nuances, the application of the legal principle of abrogation to non-Islamic traditions has shaped Islamic exclusivism, which still finds supporters in contemporary Islamic discourse. Opposite to exclusivist theology, Muslim pluralist theologians reject supersessionist theory either explicitly (Ayoub 1992; Esack 1997) or implicitly. The application of this theory can be used to identify the two-sided to the Islamic responses to other religions.

Knitter (2002) classifies exclusivism and inclusivism as replacement and fulfilment models, respectively. Similar to Race's exclusivism, while the first model explores Protestant theologies, the second model engages with Catholic theologies. The main difference between these two models is their understanding of revelation. While the first model either rejects (Total Replacement) or partially agrees (Partial Replacement) with the idea that revelation can be found outside of the Christian faith, the second model accepts the validity of revelations outside of Christianity by proposing that the Holy Spirit works either in the hears of non-Christians or in their religions. As a result, the first model sees Christianity as the only and final religion that leads to salvation because of the revelation in Jesus Christ, whereas the second model provides some value to non-Christian religions, though it still considers other religions to be not good as Christianity.

The Qur'ānic confirmation of other religions at first glance can be considered as fulfilling other religions. The Qur'ān mentions other religions and earlier revelations that validate non-Islamic tradition. However, with supersessionist theory, the positive affirmation of non-Muslims has been disregarded. A popular assumption of Muslims is that there were true revelations before the Qur'ān, these revelations [given to Christians and Jews] were corrupted and changed, and as a result, their religions can no longer be considered as true religions. This view accepts the reality of revelation outside of the Islamic faith but simultaneously invalidates their religions via supersessionist theory. Thus, the Islamic account of supersessionism can be viewed as a Replacement Model versus a Fulfillment model.

\section{Contemporary Islamic Responses to Religious Pluralism}

I have already indicated that one of the main arguments of this paper is that contemporary Muslims offer a two-sided response to religious pluralism. I will briefly explain these arguments.

When scholars discuss Islamic exclusivism, the first model they mention is the sociopolitical rejection of non-Islamic religions ${ }^{24}$ as if this position is a popular position among Muslims. However, it should be noted that the traditional form of exclusivism has had major support from Muslin theologians since the early years of Islam. Hereby, there are two forms of exclusivism in contemporary discourse: socio-political and theological exclusivism. The proponents of the first type find their roots in the Islamic revivalist movements of the early twentieth century. In this type of exclusivism, the social, political, economic, and theological values of non-Islamic religions (systems) are rejected as well as their theologies (Qutb and Mawdudi). Their interpretation of the Qur'ānic verses is based on the radical exclusion of others. In the contemporary period, Yasir Qadhi and Winter offer more sophisticated theological exclusivism, which takes reference from mainstream Sunni orthodoxy. The main idea of this type is that Islam is the only true religion and that it supersedes other religions, an idea that takes its roots from Qur'ānic affirmation (Qadhi 2013; Winter 2013). Moreover, the Prophet Muhammad's actions provide enough evidence to claim Islam's superiority, and for them, traditional Islamic scholars had already provided the Islamic position towards other faiths. As for the fate of non-Muslims, they are not pessimistic; they either leave their fate to God (Qadhi 2013) or consider the Prophet's intercession for both Muslims and non-Muslims (Winter 2013).

Islamic pluralism, however, is a modern concept. Through the reception of liberal arguments in academia, Muslim theologians have started to use different hermeneutical methodologies in order to offer a pluralistic vision of the Qur'ān. The main characteristics 
of the theologies of Muslim pluralist theologians is that all have been persuaded of the universality of God and His message(s), which they share with exclusivist theory. However, while exclusivism claims that the only valid universal message of God is supplied by Islam, pluralists disagree with that argument. They mainly try to reconcile the universality of God's message with the existence of other religious traditions. In the contemporary period, diverse variations in pluralism exists in the Islamic theology of religions. Although Muslim pluralists construct different theologies, they are more or less in agreement with two ideas; that the diversity of God's will and the word of "Islam" does not only refer to the religion of Muslims, which they differentiate between historical/institutional and universal Islam. Among Muslim pluralists, we see the influence of John Hick and Cantwell Smith, which constitutes one type of Islamic pluralism. This type of pluralism can be called theocentric pluralism, and the term was originally proposed by Knitter 1985. Soroush, Ayoub, Askari, Aydin, Atay, and Engineer are in this group. The main argument for this kind of pluralism is that they overemphasise universal Islam and devalue historical Islam. In addition, echoing Hick's famous claim that religions are different responses to the divine Reality (Hick 1989), some Muslim pluralists also think that each religion (Abrahamic faiths) has an equally and differently authentic approach to the "Absolute Truth" (Askari 1985). Another form of pluralism comes from Farid Esack. From his struggle in the South African apartheid regime and from the influence of liberation theology, Esack (1997) offers liberation pluralism, which emphasises good deeds as well as belief. Rather than theocentrism, this form of pluralism prioritises the Qur'ānic vision of egalitarianism and cooperation with non-Muslims for the common good. We see the Sufi influence on contemporary Islamic pluralism in Nasr and Shah-Kazemi's theologies. Taking some Sufi interpretations, such as Ibn 'Arabī, as a starting point, their main claim is that different religions are divinely ordained. They validate each religion since they think that everything in this world, including religions, owes their existence to the absolute reality of God.

I have presented the two-sided Islamic positions towards other religions. As it is clear from their theologies of religions, we see that in the contemporary period, exclusivism and pluralism centralise Islamic responses towards others. There are diverse positions, and each theologian's nuance is different, but if we have to categorise them, the best way to do so is to divide these responses into two categories rather than three.

\section{Conclusions}

I have demonstrated different applications foe Race's and Lamptey's three-fold typologies. Khalil, Atay, and Winkler's accounts of exclusivism and pluralism follow the original typology, but their accounts of inclusivism are problematic since they either include exclusivist theology into inclusivism (in Khalil's case) or do not differentiate between inclusivism and pluralism enough (Atay and Winkler). The difficulty is that this typology has been developed in the light of Christian attitudes towards others. Since Islamic and Christian theologies are constructed in different ways, the use of different objects, i.e., Christ or the Qur'ān, in their theological responses to other beliefs is natural. Hence, when the typology is transferred to the Islamic theology of religions, these scholars have tried to follow something equivalent in the Islamic theology of religions. Rather than demonstrating the main camps in the Islamic response to religious others, they try to fit theologians into three different categories, something that they all eventually failed in doing because of their overdependence on a three-fold typology. I have also shown that Lamptey's three-fold typology does not depict the contemporary Islamic theology of religions because her categories do not include all of the theologians that she has evaluated, including her own theology. Thus, I have offered that although Islamic responses to religious diversity in the contemporary period have been varied, these responses to religious pluralism can be categorised into two types: exclusivism and pluralism. The supersessionist theory can be used to justify this division. Thus, on the one hand, Islamic exclusivism considers Islam as the only valid and superior religion that supersedes other religions; on the other hand, Islamic pluralism values non-Islamic traditions by offering a universal vision of Islam. 
Christian scholars have been discussing the usefulness of Race's classification. Hedges (2008) claims that rather than seeing typology as prescriptive, normative, defining, and closed, it should be seen as a descriptive, heuristic, multivalent, and permeable. Race's typology as well as the additions that have been made to it by other scholars helps us to see the main tendencies (Hedges 2016) among the perspectives that Christian theologians have regarding non-Christian religions. Likewise, if we identify the main tendencies within Islamic theology correctly, rather than imposing a typology which was constructed within Christian thought, it provides us a better picture of what kind of theology was developed from the early days of Islam, how modern/liberal theologies challenge traditional or conservative theologies, how contemporary Muslims develop theologies of other religions, and so on.

Funding: This research received no external funding.

Institutional Review Board Statement: Not applicable.

Informed Consent Statement: Not applicable.

Data Availability Statement: Not applicable.

Conflicts of Interest: The author declares no conflict of interest.

\section{Notes}

For a good overview of Race's typology and its defense, see: (Schmidt-Leukel 2005) and (Hedges 2008).

For an example, see (Demichelis 2018)

He uses Acts 2.12: "And there is no salvation in no one else, for there is no other name under heaven given among men by which we must be saved,' and John 14.6: 'I am the way, and the truth, and the life; no one comes to the Father, but by me" 1993.

For example, see (D'Costa 1986)

Knitter (1985) offers four models: the Conservative Evangelical Model, the Mainline Protestant Model, the Catholic Model, and the Theocentric Model, which are modified versions of a three-fold typology. His first two models describe exclusivism, and the latter two describe inclusivism and pluralism, respectively.

$6 \quad$ Knitter (2002) offered four models: Replacement, Fulfillment, Mutuality, and Acceptance. His first three models echo Race's three-fold typology while exploring post-liberal theology and comparative theology within the Acceptance Model. Paul Hedges, unlike Knitter, follows Race's typology and, similar to Knitter, he adds particularist theology as the fourth category (Hedges 2010) See note 1.

For example, see (Harris et al. 2016; Race and Hedges 2008).

For example, in the contemporary period, Shah-Kazemi (2006) uses Ibn 'Arabī to justify his universalist position, and Aydin (2005a) modifies Rumi's thoughts to offer pluralism.

He uses the word of universalism to refer to the view that assumes that everyone will be granted everlasting life in Paradise.

Winter follows traditional Islamic views (Ash'arī and Māturīdī) of other beliefs. He believes that the Qur'ān itself declares Islam to be a supersessionist religion. For the salvation of non-Muslims, Winter leaves the door open for sincere non-Muslims.

This is the term he intentionally chose to indicate different variations of Islamic pluralism.

D'Costa (2009) divides exclusivism into two categories: restrictive-access and universal-access exclusivists. The first group emphasises the necessity of Jesus Christ for salvation, as they believe God has chosen some for salvation and others for damnation, whereas the second group highlights the universal salvific will of God.

For the inclusivist position, he uses Aydin (2001), and for pluralism, he uses Aydin (2005b).

Aslan defines himself neither as pluralist nor as an inclusivist. However, Aydin has promoted pluralistic views on several occassions. See above-mentioned bibliographies.

For a good comparison between Hick and Nasr's theology of religions, see (Aslan 1999).

For Saeed, exclusivism is set by a couple of ideas: Islam is the only valid religion; salvation is only possible through following the Islamic beliefs set by the Prophet Muhammad; and the scriptures of non-Islamic religions are invalid and corrupted. Inclusivism, on the other hand, he accepts the validity of other religions and their scriptures and the possibility of salvation for non-Muslims. For example, Hick's Real Centered pluralism removes Christ and puts the Real in the center.

For the cooperation of Muslims with non-Muslims, see (Esack 1997).

Most Muslim pluralists advocate pluralism within their works though their understandings of pluralism may differ.

For a critical overview of this verse, see Burton (Burton 1985). 


\section{References}

Askari, Hasan. 1985. Within and Beyond Experience of Religious Diversity. In The Experience of Religious Diversity. Edited by John Hick and Hasan Askari. Aldershot: Gower Publishing.

Aslan, Adnan. 1999. Religious Pluralism in Christian and Islamic Philosophy: The Thought of John Hick and Seyyed Hossein Nasr. London: Routledge.

Atay, Rifat. 2014. Religious Pluralism and Islam: A Critical Reading of John Hick's Pluralistic Hypothesis. Chisinau: Scholar's Press.

Aydin, Mahmut. 2001. Religious Pluralism: A Challenge for Muslims-A Theological Evaluation. Journal of Ecumenical Studies 38: 330-52.

Aydin, Mahmut. 2005a. A Muslim Pluralist: Jalaluddin Rumi. In Myth of Religious Superiority. Edited by Paul Knitter. Ossining: Orbis Books, pp. 220-36.

Aydin, Mahmut. 2005b. Religious Pluralism. In Muslim and Christian Reflection of Peace: Divine and Human Dimension. Edited by John Woodberry, Osman Zümrüt and Mustafa Köylü. Lanham: University of Press of Amerika, pp. 89-99.

Ayoub, Mahmoud. 1992. The Qur'an and Its Interpreters, Volume II: The House of 'Imran. Albany: State University of New York Press.

Burton, John. 1985. The exegesis of Q. 2: 106 and the Islamic theories of naskh: Mā nansakh min āya aw nansahā na'ti bi khairin minhā aw mithlīhā. Bulletin of the School of Oriental and African Studies 48: 452-69. [CrossRef]

D'Costa, Gavin. 1986. Theology and Religious Pluralism: The Challenge of Other Religions. Hoboken: Wiley-Blackwell.

D'Costa, Gavin. 2009. Christianity and World Religions: Disputed Questions in the Theology of Religions. Hoboken: Wiley-Blackwell.

Demichelis, Marco. 2018. Salvation and Hell in Classical Islamic Thought: Can Allah Save Us All? London: Bloomsbury Publishing.

Engineer, Ali. 2005. Islam and Pluralism. In The Myth of Religious Superiority: A Multifaith Exploration. Edited by Paul Knitter. Ossining: Orbis Books, pp. 211-19.

Esack, Farid. 1997. Qur'an, Liberation and Religious Pluralism: An Islamic Perspective of Interreligious Solidarity against Oppression. London: One World Publications.

Freidman, Yohanan. 2003. Tolerance and Coercion in Islam: Interfaith Relations in the Muslim Tradition. Cambridge: Cambridge University Press.

Griffiths, Paul. 1990. Christianity Through Non-Christian Eyes. Ossining: Orbis Books.

Harris, Elizabeth, Paul Hedges, and Shanthikumar Hettiarachchi, eds. 2016. Twenty-First Century Theologies of Religions: Retrospection and Future Prospects. Leiden: Brill.

Hedges, Paul. 2008. A Reflection on Typologies: Negotiating a Fast-Moving Discussion. In Christian Approaches to Other Faiths. Edited by Alan Race and Paul Hedges. London: SCM Press, pp. 17-33.

Hedges, Paul. 2010. Controversies in Interreligious Dialogue and the Theology of Religions. London: SCM Press.

Hedges, Paul. 2016. The Theology of Religions Typology Redefined: Openness and Tendencies. In Twenty-First Century Theologies of Religions: Retrospection and Future Prospects. Edited by Elizabeth Harris, Paul Hedges and Shanthikumar Hettiarachchi. Leiden: Brill.

Hick, John. 1989. An Interpretation of Religion. New York: Macmillan.

Khalil, Mohammad Hassan. 2011. Salvation and the 'Other' in Islamic Thought: The Contemporary Pluralism Debate. Religion Compass 5: 511-19. [CrossRef]

Khalil, Mohammad Hassan. 2012. Islam and the Fate of Others: The Salvation Question. Oxford: Oxford University Press.

Knitter, Paul. 1985. No Other Name? Ossining: Orbis Books.

Knitter, Paul. 2002. Introducing Theologies of Religions. Ossining: Orbis Books.

Lamptey, Jerusha Tanner. 2014. Never Wholly Other: A Muslima Theology of Religions. Oxford: Oxford University Press.

Legenhausen, Mohammad. 2013. NonReductive Pluralism and Religious Dialogue. In Between Heaven and Hell: Islam Salvation and the Fate of Others. Edited by Mohammad Hassan Khalil. Oxford: Oxford University Press.

Nasr, Seyyed Hossein. 2008. Islam and the Encounters of Religions. In The Religious Other: Towards a Muslim Theology of Religious Other in a Post-Prophetic Age. Edited by S. Umar. Lahore: Iqbal Academy Pakistan.

Qadhi, Yasir. 2013. The Path of Allah or the Paths of Allah? Revisiting Classical and Medieval Sunni Approaches to Salvation of Others. In Between Heaven and Hell: Islam, Salvation and the Fate of Others. Edited by Mohammad Hassan Khalil. Oxford: Oxford University Press, pp. 110-22

Race, Alan. 1993. Christians and Religious Pluralism: Patterns in the Christian Theology of Religions, 2nd ed. London: SCM Press.

Race, Alan, and Paul Hedges, eds. 2008. Christian Approaches to Other Faiths. London: SCM Press.

Sachedina, Abdulaziz. 2006. The Qur'an and Other Religions. In The Cambridge Companion to the Qur'an. Edited by Jane Dammen McAuliffe. Cambridge: Cambridge University Press, pp. 291-309.

Saeed, Abdullah. 2020. Inclusivism and Exclusivism among Muslims Today between Theological and Social Dimensions. Singapore: Interreligious Relations, p. 21. 
Schmidt-Leukel, Perry. 2005. Exclusivism, Inclusivism and Pluralism. In The Myth of Religious Superiority. Edited by Paul Knitter. Ossining: Orbis Books, pp. 13-27.

Schmidt-Leukel, Perry. 2016. Pluralist Approaches in Some Major Non-Chritstian Religions. In Twenty-First Century Theologies of Religions: Retrospection and Future Prospects. Edited by Elizabeth Harris, Paul Hedges and Shanthikumar Hettiarachchi. Leiden: Brill, pp. 159-91.

Schmidt-Leukel, Perry. 2017. Religious Pluralism and Interreligious Theology: The Gifford Lectures—An Extended Edition. Ossining: Orbis Books.

Shah-Kazemi, Reza. 2006. The Other in the Light of One: The Universality of the Qur'an and Interfaith Dialogue. Cambridge: Islamic Texts Society.

Thomas, David. 2013. Islam and Religious Other. In Understanding Interreligious Relations. Edited by David Cheetham, Douglas Pratt and David Thomas. Oxford: Oxford University Press, pp. 148-72.

Winkler, Levis. 2011. Contemporary Muslim and Christian Responses to Religious Pluralism: Wolfhart Pannenberg in Dialogue with Abdulaziz Sachedina. Eugene: Pickwick Publications.

Winter, Tim. 1999. The Last Trump Card: Islam and Supersession of Other Faiths. Studies in Interreligious Dialogue 9: 133-55. [CrossRef]

Winter, Tim. 2013. Realism and the Real. In Between Heaven and Hell: Islam, Salvation and the Fate of Others. Edited by Mohammas Hassan Khalil. Oxford: Oxford University Press, pp. 123-55. 